\title{
Skermanella aerolata sp. nov., isolated from air, and emended description of the genus Skermanella
}

Correspondence

Soon-Wo Kwon

swkwon@rda.go.kr
Hang-Yeon Weon, ${ }^{1}$ Byung-Yong Kim, ${ }^{2}$ Seung-Beom Hong, ${ }^{2}$ Jae-Ho Joa, ${ }^{3}$ Sang-Sik Nam, ${ }^{4}$ Ki Hwan Lee ${ }^{5}$ and Soon-Wo Kwon ${ }^{2}$

\author{
${ }^{1}$ Applied Microbiology Division, National Institute of Agricultural Science and Technology, \\ Rural Development Administration, Suwon 441-707, Republic of Korea \\ ${ }^{2}$ Korean Agricultural Culture Collection (KACC), Microbial Genetics Division, National Institute \\ of Agricultural Biotechnology, Rural Development Administration, Suwon 441-707, \\ Republic of Korea \\ ${ }^{3}$ National Institute of Subtropical Agriculture, Rural Development Administration, Jeju 690-150, \\ Republic of Korea \\ ${ }^{4}$ Mokpo Experiment Station, National Institute of Crop Science, Rural Development \\ Administration, Muan 534-833, Republic of Korea \\ ${ }^{5}$ Taean Lily Experimental Station, Chungnam Provincial Agricultural Research and Extension \\ Services, Taean 357-952, Republic of Korea
}

\begin{abstract}
A light-pink-coloured bacterium, designated strain $5416 \mathrm{~T}-32^{\top}$, was isolated from an air sample in Korea. Cells of the strain were strictly aerobic, Gram-negative, motile (single polar or subpolar flagellum) and rod-shaped. Optimal growth occurred at $25-30^{\circ} \mathrm{C}$ and at $\mathrm{pH} 6.0-7.0$. The major quinones were $\mathrm{Q}-10$ and $\mathrm{Q}-8$. The major fatty acids were $\mathrm{C}_{18: 1} \omega 7 c(53.8 \%)$ and $\mathrm{C}_{16: 0}(15.9 \%)$. The $\mathrm{G}+\mathrm{C}$ content of the genomic DNA was $65.0 \mathrm{~mol} \%$. Phylogenetic analysis based on 16S rRNA gene sequences revealed that strain $5416 \mathrm{~T}-32^{\top}$ was most closely related to Skermanella parooensis, with a similarity of $96.2 \%$, but relatively low sequence similarities (<92\%) were found with respect to other species with validly published names held in GenBank. Phenotypic and genotypic analyses indicated that strain $5416 \mathrm{~T}-32^{\top}$ could not be assigned to any recognized species. Therefore strain $5416 \mathrm{~T}-32^{\top}$ represents a novel species of the genus Skermanella, for which the name Skermanella aerolata sp. nov. is proposed. The type strain is $5416 \mathrm{~T}-32^{\top}(=\mathrm{KACC}$ $11604^{\top}=$ DSM $18479^{\top}$ ).
\end{abstract}

Conglomeromonas largomobilis subsp. parooensis was first proposed by Skerman et al. (1983). Later, this taxon was reclassified as Skermanella parooensis gen. nov., sp. nov. on the basis of polyphasic taxonomic evidence (Sly \& Stackebrandt, 1999). The genus was phylogenetically related to the genus Azospirillum of the Alphaproteobacteria, and was characterized as a Gram-negative, motile, high $\mathrm{G}+\mathrm{C}$ containing facultative anaerobe. The only species (and therefore the type species) is $S$. parooensis.

When violent sandstorms happen in northern China or Mongolia, they produce lots of fine particles that float at a

The GenBank/EMBL/DDBJ accession number for the 16S rRNA gene sequence of strain $5416 \mathrm{~T}-32^{\top}$ is D0672568.

The cellular fatty acid profiles of strain $5416 \mathrm{~T}-32^{\top}$ and Skermanella parooensis CIP $106994^{\top}$ are available in a supplementary table with the online version of this paper. high altitude. These fine particles drift to the Korean peninsula in the spring. This is referred to as the Asian dust ('Hwangsa' in Korean) phenomenon, and usually happens between March and May.

To compare the airborne bacteria in Asian dust with those present normally, air samples were collected with a MAS100 air sampler (a single-stage, multiple-hole impactor; Merck) on the roof of Taean Lily Experimental Station (Chungnam Provincial Agricultural Research and Extension Services in the Taean district of Korea) on 16 April 2005. The sample volume $(20-1000 \mathrm{cc})$ was chosen on the basis of the bacterial concentration expected at each site. The sampler contained Petri dishes with R2A agar (BBL) supplemented with $200 \mu \mathrm{g}$ cycloheximide $\mathrm{ml}^{-1}$ (Sigma). After sampling, the plates were incubated in the dark at $28^{\circ} \mathrm{C}$ for 5 days. During this process, we isolated a light-pink-coloured bacterium, designated strain $5416 \mathrm{~T}-32^{\mathrm{T}}$. 
Unless indicated otherwise, phenotypic characteristics were studied by using standard procedures (Smibert \& Krieg, 1994). Growth under anaerobic conditions was tested in a GasPak (BBL) jar at $28^{\circ} \mathrm{C}$ for 15 days on R2A and nutrient agar (Difco). Strain 5416T-32 ${ }^{\mathrm{T}}$ was grown in R2A medium for $48 \mathrm{~h}$ at $28^{\circ} \mathrm{C}$ to check the morphology using phasecontrast microscopy and transmission electron microscopy. Several other physiological characteristics, plus the utilization of various sole carbon sources, were determined with the API ID 32 GN, API 20NE, API $50 \mathrm{CH}$ and API ZYM galleries, according to the instructions of the manufacturer (bioMérieux). The API ZYM tests were read after $4 \mathrm{~h}$ incubation at $37^{\circ} \mathrm{C}$ and the other API tests were read after 4 days at $28^{\circ} \mathrm{C}$.

Strain $5416 \mathrm{~T}-32^{\mathrm{T}}$ is a strictly aerobic, Gram-negative, motile (single polar or subpolar flagellum), rod-shaped bacterium $(0.6-1.2 \times 1.5-3.5 \mu \mathrm{m})$. The colonies are light pink in colour, convex and round with clear margins. It grows on R2A, nutrient agar, trypticase soy agar (Difco) and MacConkey agar (Difco). Strain 5416T-32 ${ }^{\mathrm{T}}$ can be distinguished from $S$. parooensis in that the former can grow at higher $\mathrm{NaCl}$ concentrations (up to $5 \%$ ) and lower temperatures (down to $5{ }^{\circ} \mathrm{C}$ ) and can hydrolyse CM-cellulose, but lacks the ability to hydrolyse DNA. According to the assimilation tests with the API 20NE and API ID 32 GN strips, two strains, 5416T-32 ${ }^{\mathrm{T}}$ and S. parooensis CIP $106994^{\mathrm{T}}$, showed some differences in the pattern of substrate utilization. However, in fermentation tests performed using API $50 \mathrm{CH}$ strips, the two strains produced almost identical fermentation patterns, except that strain $5416 \mathrm{~T}-32^{\mathrm{T}}$ was able to ferment D-galactose and Dglucose. A phenotypic comparison between strain 5416T-32 ${ }^{\mathrm{T}}$ and S. parooensis is presented in Table 1.

Isoprenoid quinones were extracted from lyophilized cells and analysed by HPLC as described previously (Groth et al., 1996). Whole-cell fatty acids were analysed according to the standard protocol of the MIDI/Hewlett Packard Microbial Identification System (Sasser, 1990) after cell cultivation on R2A for 2 days at $28^{\circ} \mathrm{C}$. The DNA G $+\mathrm{C}$ content of strain 5416T-32 ${ }^{\mathrm{T}}$ was determined according to Mesbah et al. (1989), using a reversed-phase column (Supelcosil LC-18-S; Supelco). The major isoprenoid quinones were Q-10 and Q-8. A small amount of Q-6 was also detected. Strain 5416T-32 $2^{\mathrm{T}}$ contained $\mathrm{C}_{18: 1} \omega 7 c(53.8 \%)$ and $\mathrm{C}_{16: 0}(15.9 \%)$ as the predominant fatty acids, and no significant differences in the fatty acid profiles were found between strain 5416T-32 ${ }^{\mathrm{T}}$ and S. parooensis CIP $106994^{\mathrm{T}}$ (see Supplementary Table S1, available in IJSEM Online). The DNA $\mathrm{G}+\mathrm{C}$ content of strain $5416 \mathrm{~T}-32^{\mathrm{T}}$ was $65.0 \mathrm{~mol} \%$.

Amplification and sequencing of the 16S rRNA gene were performed as described previously (Kwon et al., 2003). The sequence obtained was compared with those in GenBank by using DNASTAR software. The sequences were aligned by using CLUSTAL W software (Thompson et al., 1994). Distances were calculated according to the methods of Kimura (1980). Phylogenetic trees were inferred by using the neighbour-joining method (Saitou \& Nei, 1987). A
Table 1. Phenotypic comparison of strain $5416 \mathrm{~T}-32^{\top}$ and S. parooensis CIP $106994^{\top}$

Data for S. parooensis CIP $106994^{\mathrm{T}}$ are from Sly \& Stackebrandt (1999) and this study. Both strains are positive for nitrate reduction, urea hydrolysis, gelatin hydrolysis and $\beta$-galactosidase (API $20 \mathrm{NE}$ ). Both are negative for anaerobic growth and for glucose fermentation (though these two results are not in line with the results from the original description by Sly \& Stackebrandt, 1999) and for indole production, arginine dihydrolase and aesculin hydrolysis. Both strains assimilate D-glucose, L-arabinose, D-mannose, D-mannitol, potassium gluconate, malic acid, D-ribose, sodium malonate, lactic acid, L-alanine, L-fucose, D-sorbitol, propionic acid, potassium 2-ketogluconate, 3-hydroxybutyric acid and L-proline. Neither strain assimilates $\mathrm{N}$-acetylglucosamine, D-maltose, capric acid, adipic acid, trisodium citrate, phenylacetic acid, inositol, D-sucrose, itaconic acid, potassium 5-ketogluconate, glycogen, 3-hydroxybenzoic acid, L-serine, salicin, D-melibiose or L-histidine (API 20NE and API ID $32 \mathrm{GN}$ ). Both strains show alkaline phosphatase, esterase (C4), esterase lipase (C8), leucine arylamidase, acid phosphatase and naphthol-AS-BI-phosphohydrolase activities. Neither strain shows lipase (C14), valine arylamidase, cystine arylamidase, trypsin, $\alpha$-chymotrypsin, $\alpha$-galactosidase, $\beta$-galactosidase, $\beta$-glucuronidase, $N$-acetyl- $\beta$-glucosaminidase, $\alpha$ mannosidase or $\alpha$-fucosidase activity (API ZYM).

\begin{tabular}{|c|c|c|}
\hline Characteristic & $\begin{array}{c}\text { Strain } \\
5416 \mathrm{~T}-32^{\mathrm{T}}\end{array}$ & $\begin{array}{l}\text { S. parooensis } \\
\text { CIP } 106994^{T}\end{array}$ \\
\hline Source & Air & Fresh water* \\
\hline \multicolumn{3}{|l|}{ Growth at: } \\
\hline $5^{\circ} \mathrm{C}$ & + & $-{ }^{*}$ \\
\hline $5 \% \mathrm{NaCl}$ & + & $-{ }^{*}$ \\
\hline \multicolumn{3}{|l|}{ Hydrolysis of: } \\
\hline Cellulose & + & $-*$ \\
\hline DNA & - & $+^{*}$ \\
\hline \multicolumn{3}{|c|}{ Assimilation of (API 20NE and API ID 32 GN): } \\
\hline L-Rhamnose & - & + \\
\hline Suberic acid & + & - \\
\hline Sodium acetate & - & + \\
\hline Valeric acid & - & + \\
\hline 4-Hydroxybenzoic acid & - & + \\
\hline \multicolumn{3}{|l|}{ Enzymic activities (API ZYM): } \\
\hline$\alpha$-Glucosidase & - & + \\
\hline$\beta$-Glucosidase & - & + \\
\hline DNA G $+C$ content $(\mathrm{mol} \%)$ & 65 & $67^{*}$ \\
\hline
\end{tabular}

${ }^{\star}$ Data from Sly \& Stackebrandt (1999).

bootstrap analysis was performed on the basis of 1000 resamplings. The MEGA version 2.1 package (Kumar et al., 2001) was used for the analysis.

An almost-complete 16S rRNA gene sequence (1365 nt) for isolate $5416 \mathrm{~T}-32^{\mathrm{T}}$ was obtained. Sequence comparisons with species with validly published names (obtained from GenBank) indicated that strain $5416 \mathrm{~T}-32^{\mathrm{T}}$ is related phylogenetically to members of the genera Skermanella, Azospirillum and Rhodocista (within the Alphaproteo- 


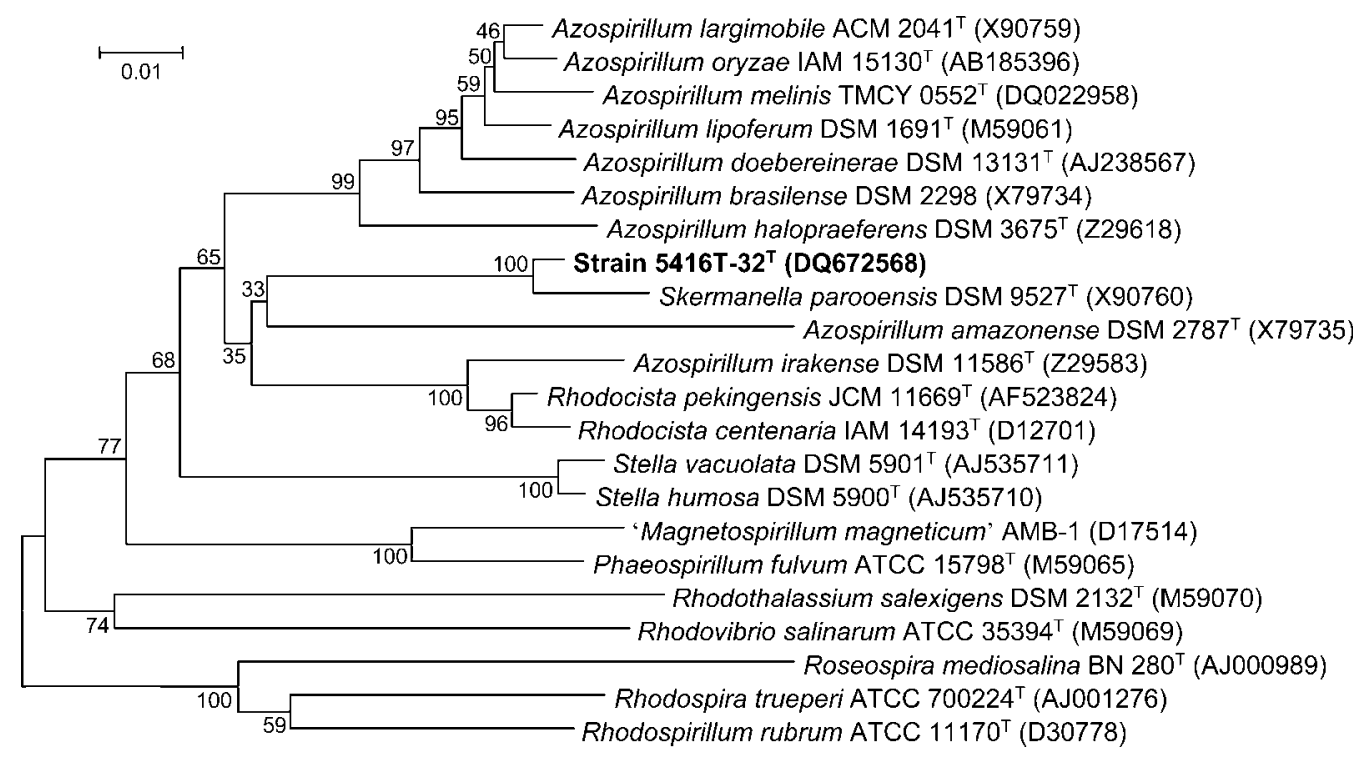

Fig. 1. Neighbour-joining phylogenetic tree, based on $16 \mathrm{~S}$ rRNA gene sequences, showing the position of strain $5416 \mathrm{~T}-32^{\top}$ within the family Rhodospirillaceae. Bar, 1 inferred substitution per $100 \mathrm{nt}$. Numbers at branch points are bootstrap percentages (of 1000 resamplings).

bacteria). The phylogenetic tree (Fig. 1) showed that strain $5416 \mathrm{~T}-32^{\mathrm{T}}$ forms a separate cluster with $S$. parooensis DSM $9527^{\mathrm{T}}$ (with $100 \%$ bootstrap support). The sequence comparisons also showed that the 16S rRNA gene sequence of strain $5416 \mathrm{~T}-32^{\mathrm{T}}$ exhibits the highest level of similarity $(96.2 \%)$ with S. parooensis DSM $9527^{\mathrm{T}}$ but has relatively low levels of sequence similarity $(<92 \%)$ with respect to other species with validly published names held in GenBank.

The genetic and phenotypic data presented above show that strain $5416 \mathrm{~T}-32^{\mathrm{T}}$ represents a novel species of the genus Skermanella, for which the name Skermanella aerolata sp. nov. is proposed.

\section{Emended description of the genus Skermanella Sly and Stackebrandt 1999}

The description is as given by Sly \& Stackebrandt (1999), except that the genus is negative for glucose fermentation and is strictly aerobic.

\section{Description of Skermanella aerolata sp. nov.}

Skermanella aerolata (ae.ro.la'ta. Gr. n. aer air; L. part. adj. lata carried; N.L. part. adj. aerolata airborne).

Cells are strictly aerobic, Gram-negative rods, and motile by means of a single polar or subpolar flagellum. Temperature range for growth is $5-35^{\circ} \mathrm{C}$. Growth occurs with $\mathrm{NaCl}$ concentrations in the range $0-5 \%$ and at $\mathrm{pH} 4-9$. Poly- $\beta$ hydroxybutyrate is produced. Positive for catalase, oxidase and hydrolysis of CM-cellulose, starch and Tween 80 . Negative for Voges-Proskauer test, for the deamination of phenylalanine and for hydrolysis of casein, chitin, DNA, pectin and tyrosine. Ferments D-arabinose, L-arabinose, D-ribose, D-xylose, L-xylose, D-galactose, D-glucose, D-melibiose and D-lyxose, but does not ferment glycerol, erythritol, D-adonitol, methyl $\beta$-D-xylopyranoside, D-fructose, D-mannose, L-sorbose, L-rhamnose, dulcitol, inositol, D-mannitol, D-sorbitol, methyl $\alpha$-D-mannopyranoside, methyl $\alpha$-Dglucopyranoside, $\mathrm{N}$-acetylglucosamine, amygdalin, arbutin, aesculin, salicin, D-cellobiose, D-maltose, D-lactose, Dsucrose, D-trehalose, inulin, D-melezitose, D-raffinose, starch, glycogen, xylitol, gentiobiose, D-turanose, D-tagatose, D-fucose, L-fucose, D-arabitol, L-arabitol, potassium gluconate, potassium 2-ketogluconate or potassium 5-ketogluconate (API $50 \mathrm{CH}$ strips). Major respiratory lipoquinones are Q-10 and Q-8. Major fatty acids are $\mathrm{C}_{18: 1} \omega 7 c$ and $\mathrm{C}_{16: 0}$. The $\mathrm{G}+\mathrm{C}$ content of the genomic DNA of the type strain is $65.0 \mathrm{~mol} \%$.

The type strain, 5416T $-32^{\mathrm{T}} \quad\left(=\mathrm{KACC} \quad 11604^{\mathrm{T}}=\mathrm{DSM}\right.$ $\left.18479^{\mathrm{T}}\right)$, was isolated from air in Taean, Republic of Korea.

\section{Acknowledgements}

This study was supported by the National Institute of Agricultural Biotechnology (NIAB grant no. 06-4-11-19-1), Rural Development Administration, Republic of Korea.

\section{References}

Groth, I., Schumann, P., Weiss, N., Martin, K. \& Rainey, F. A. (1996). Agrococcus jenensis gen. nov., sp. nov., a new genus of actinomycetes with diaminobutyric acid in the cell wall. Int J Syst Bacteriol 46, 234-239.

Kimura, M. (1980). A simple method for estimating evolutionary rates of base substitutions through comparative studies of nucleotide sequences. J Mol Evol 16, 111-120. 
Kumar, S., Tamura, K., Jakobsen, I. B. \& Nei, M. (2001). MEGA2: molecular evolutionary genetics analysis software. Bioinformatics 17, 1244-1245.

Kwon, S. W., Kim, J. S., Park, I. C., Yoon, S. H., Park, D. H., Lim, C. K. \& Go, S. J. (2003). Pseudomonas koreensis sp. nov., Pseudomonas umsongensis sp. nov. and Pseudomonas jinjuensis sp. nov., novel species from farm soils in Korea. Int J Syst Evol Microbiol 53, 21-27.

Mesbah, M., Premachandran, U. \& Whitman, W. B. (1989). Precise measurement of the $\mathrm{G}+\mathrm{C}$ content of deoxyribonucleic acid by highperformance liquid chromatography. Int J Syst Bacteriol 39, 159-167.

Saitou, N. \& Nei, M. (1987). The neighbor-joining method: a new method for reconstructing phylogenetic trees. Mol Biol Evol 4, 406-425.

Sasser, M. (1990). Identification of Bacteria by Gas Chromatography of Cellular Fatty Acids, MIDI Technical Note No. 101. Newark, DE: MIDI Inc.
Skerman, V. B. D., Sly, L. I. \& Williamson, M.-L. (1983). Conglomeromonas largomobilis gen. nov., sp. nov., a sodium-sensitive, mixedflagellated organism from fresh waters. Int J Syst Bacteriol 33, 300-308.

Sly, L. I. \& Stackebrandt, E. (1999). Description of Skermanella parooensis gen. nov., sp. nov. to accommodate Conglomeromonas largomobilis subsp. parooensis following the transfer of Conglomeromonas largomobilis subsp. largomobilis to the genus Azospirillum. Int J Syst Bacteriol 49, 541-544.

Smibert, R. M. \& Krieg, N. R. (1994). Phenotypic characterization. In Methods for General and Molecular Bacteriology, pp. 607-654. Edited by P. Gerhardt, R. G. E. Murray, W. A. Wood \& N. R. Krieg. Washington, DC: American Society for Microbiology.

Thompson, J. D., Higgins, D. G. \& Gibson, T. J. (1994). CLUSTAL W: improving the sensitivity of progressive multiple sequence alignment through sequence weighting, position-specific gap penalties and weight matrix choice. Nucleic Acids Res 22, 4673-4680. 